\title{
NEW MEDIA AND DEMOCRACY IN NIGERIA: AN APPRAISAL OF THE OPPORTUNITIES AND THREATS IN THE TERRAIN
}

\author{
Dauda Ishaya Suntai ${ }^{1}$ \\ Tordue Simon Targema ${ }^{2}$
}

\section{Introduction}

The advent of the new media has, no doubt, revolutionized the process of political communication and expanded the frontiers of political participation. This is not far from the fact that the internet provides a forum for continuous interaction between the masses and the government. McQuail (2005) articulates this point when he notes that: the new media has been widely hailed as a potential way of escape from the top-down politics of mass democracies in which tightly organized political parties make policies unilaterally and mobilize support behind them with minimal negotiation and grassroots input. They provide the means for highly differentiated political information and ideas almost unlimited access in theory to all voices, and much feedback and negotiation between leaders and followers.

One vital potential of the new media, with its divergent means of information dissemination is that it has increased the volume of information at the disposal of the masses, with unlimited freedom such that the audience equally create and share content to other subscribers with ease. The fact that information is power has, thus, enabled the new media to empower the masses to participate actively in the process of governance. Democracy, which entails public participation in the process of governance, benefits immensely from this new revolution in the process of communication

I Department of Languages and Literary Studies, Taraba State University, Jalingo, Nigeria. E-mail: suntaid@yahoo.com.

2 Department of Mass Communication, Taraba State University, Jalingo, Nigeria. E-mail: torduesimon@gmail.com. 
(Suntai and Targema 2015).

Nigeria, which has been exposed to authoritarian military rules shortly after the colonial era receives this revolution with a big sigh of relief, as the authoritarian regimes left no stone unturned in the bid to muzzle the press and firmly spread the tentacles of their dictatorship and tyranny devoid of public criticisms and antagonism. With the return to democratic rule, and recent adaptation of the new media platforms, which are trending, the scope of political participation and criticisms has been widened.

Elsewhere, the Arab Spring is a testimony to the power of the new media in extending the frontiers of democracy, as social networking sites dominated the communication activities that trailed the revolution and resistance of oppressive rule in the region. The wave of revolutions that were social media driven saw oppressive leaders, such as Hosni Mubarak of Egypt, Ben Ali of Tunisia among others, having social media to blame for their public rejection and subsequent dethronement, after securely monitoring the mainstream media. Hanan $(2013,2)$, thus, describes the role of the new media in the revolutions as follows:

much have already been said about the Arab spring but what is already clear, from the current body of work being produced, is that it was the use of social media that acted as a catalyst for change in an already unpredictable environment. The use and availability of social media easily created connections between prominent thought leaders/activists and ordinary citizens, rapidly expanding the network of people willing to take action.

Elegbede (20I5) asserts that nothing big and relevant happens in Africa today without the influence of the social media. While the assertion may not be absolutely correct, we are reminded of a series of events that have unfolded, mainly through social media platforms across political, health and commercial development landscape of the continent. The bathing with and drinking salt episode as an immunity against Ebola disseminated on social media, which received massive compliance among Nigerians, is still fresh in our memory.

The 2015 general elections in Nigeria present another scenario where the entire gamut of social media was deployed to entrench the principles of democracy through what appeared to be relatively free and fair elections. According to Oseni (20I5), starting from the period of the campaign, through voting to the collation of results and subsequent declaration of winners by INEC, social media were formidable forces in keeping the masses informed. Two years into the administration of President Mohammadu Buhari, who emerged victorious during the polls, we can attest to the formidable role the new media plays in the process of governance. 
This study derives its justification from this scenario. Anchored on the Social Responsibility Theory, it explores the contribution of the new media in the entrenchment of democracy in the country, and critically assesses issues and matters arising with the adaptation of the platform by both the government and the masses.

\section{New Media and Democracy: A Conceptual Discussion}

The proliferation of new media platforms in Nigeria recently has attracted the attention of researchers to investigate the rippling effects in several fields such as the economy, education, politics and health among others. In all of these fields, research evidence has demonstrated that the platforms have proved effective in increasing access to vital information that helps people to make informed decisions (Alexander, Ifeanyi and Martin 20I6). Basically, the scope of new media (as used in this study) is broad, and encapsulates platforms such as online newspapers, social media and blogs, all of which are domiciled on the internet. Of all these, social media play leading role in filling the hitherto existing information gap, as it comfortably houses the other new media platforms on its various channels.

Social media are online communication media that use web based technologies which enable users to download, upload, interact and collaborate with one another regardless of distance and time. Social media as a concept is the use of technology combined with social interaction to create and co-create value (Olise 20I4). It is thus a shift in how people discover, read and share news, information and content which may be text, audio, video or graphics.

Media scholars argue that social media involve a fusion of sociology and technology to transform the process of communication from monologue to dialogue or better still, to an interactive process. Some of the common social media sites include Facebook, Twitter, WhatsApp, Flicker, 2go, YouTube, Instagram, and Google+ among others. These relatively new media gain popularity in Nigeria, in spite of her technological backwardness, helping to accomplish complex political tasks across the country.

According to Nwabueze (20I4), Nigeria has registered some level of presence in the internet-based community. There are numerous weblogs run by Nigerians, many of which create the forum for the masses to air their views and make meaningful contribution to topics being discussed by a chain of users. Klinreports.com, Chidiopara reports, Nairaland, Naijapost, Naija.com, Pulse Nigeria, Topic.net and Amana online among a host of others are some of the popular blogs in Nigeria. In fact, as at July 
2009, there were about 475 Nigerian blogs, with Nigeria having an online population of 42 million people (Nwabueze 20I4). This trend must have improved significantly over the years.

As one could rightly expect, the heavy online presence has widened the scope of citizen journalism practice in the country, a form of journalism where members of the public play an active role in the process of collecting, reporting, analyzing and disseminating news and information. With citizens becoming reporters of issues and events happening around them, freedom of information is enhanced, empowering them to be actively involved in the democratic process (Suntai and Targema 2015).

Democracy as a concept originates about 2400 years ago in ancient Greece. It simply means "rule by the people (Galadima and Goshit 20I3). Democracy requires that each individual be free to participate in the political community's self-government. To this end, political freedom lies at the heart of the concept of democracy. Basically, democracy connotes rule by the people through free and fair elections and other forms of participation.

According to Galadima and Goshit (2013), the Athenians of ancient Greece, progenitors of democracy, did not leave us in dearth of definition for the concept, conceiving it in their days as "government of the people, by the people and for the people". To this end, democracy entails popular sovereignty, political equality, recognition of the consent of the governed as well as free and fair elections among other forms of participation.

Democracy puts accent on people's participation. Everyone involved should be carried along, and this is where the role of the media becomes necessary. Thus, an environment of dialogue is sine qua non for the sustenance of democracy, but this cannot be achieved unless the media and other essential fabrics that hold democratic institutions are in place. The trending social media and citizen journalism that allow for participation and unlimited access to all, among other virtues, are thus central to the sustenance of modern democracies.

However, central to the exercise of this civic responsibility is the volume of information at the disposal of the masses to take informed decisions all through the electoral process, and that is why Gambo (2013) stresses that liberal democracies rests purely on the capacity of the mass media to gather and disseminate information that can guide citizens in making rational choices. Citing Ibrahim, he notes that:

For the people to be able to determine who wants to rule them based on an understanding of his policies as well as what structures etc. are preferable in the society presupposes a certain amount of knowledge and information which must be supplied ...the availability of neutral information about the functioning of the political system makes it 
possible for the electorate of a democracy to perform its recruitment function intelligibly and effectively and at the same time tends to create an informed stratum of citizens who are public policy-oriented rather than interest oriented in a narrow sense (Gambo 20I3, IO9).

This is where the nexus between new media and democracy lies. While democracy needs adequate information to filter through its various levels, the new media provide the best platform for the circulation of such information. Through its various platforms, the masses get exposed to information about the activities of the principal actors in the process of governance. Thus, new media has become a formidable force that drives contemporary Nigerian democracy.

\section{Social Responsibility: the Theoretical Bedrock}

Social responsibility theory draws the attention of journalists to the fact that they have freedom attach with responsibility to the society. According to Bitner (1989), by the turn of the twentieth century, the printed press had been through the era of yellow journalism (a kind of journalism characterized by reckless reporting and unethical practice). Prior to this era, the press, through the efforts of freedom fighters such as John Milton, John Erskine, Thomas Jefferson and John Stuart Mill attained some considerable degree of freedom to operate without restrictions (formal/informal, constitutional or otherwise) in place (Sambe 2008).

There was thus a great need for self-moderation by journalists who were already abusing the excessive freedom. The social responsibility theory, thus, came on board. Central to the core assumptions of the theory is the fact that the press has the right to criticize government and institutions, but also has certain basic responsibilities to maintain the stability of society. Nurturing this theory is the rise of professional associations associated with Journalism globally; such as the American Society of Newspaper Editors, the Nigerian Union of Journalists, Nigerian Guild of Editors etc., and the evolution of codes of conduct/ethics that encourages responsible action by their members.

With the advent of the new media that has conferred unto every citizen the status of a journalist; the scope of freedom of expression has been extended. No doubt, the various platforms have liberalized the market place of ideas, and have removed the least official barriers to freedom of expression in countries like Nigeria, where the state allows for free interaction on the various platforms.

However, with the public assuming the role of reporters and 
professional journalists as citizen journalists via the various new media platforms, there is a great need to re-interrogate the social responsibility question. These issues quickly surge forward: can citizen journalists and members of the general public abide by the ethics standards of the profession in their reportage of activities around them? Can one rely on information by citizen journalists and social media accounts as substitutes for news in the mainstream media? Is there any need to enact rules and regulations so as to checkmate reckless spread of information on the social media platforms? After all, how does the spread of incredible information on social media platforms effect the entrenchment of democracy and national unity/ cohesion in Nigeria? Answers to these questions have become pressing, given the current level of abuse which the platforms have been subjected to, as will be discussed in the subsequent sections of the study.

\section{New Media and Democracy in Nigeria: Some Basic observations}

Democracy benefits a lot from the opportunities offered by the new media which attracts active youths that interact constantly on the various platforms. In contemporary Nigeria, new media platforms, such as social media, are agog with youths and members of the general public to the extent that the political class is compelled to key into this new technology to sustain their relevance. In the words of Adeyanju (2013, 20I):

The expanded information in public sphere and the quantum of information at the disposal of the citizens are making it imperative for those interested in public opinion to change their strategies at influencing it. Many politicians and governments are now moving fast to imbibe the new media and even the social media to get their messages across to the people. The traditional media are no longer enough to do this. It is becoming very common to see politicians have their own blogs and chat constantly with their audience on Facebook while at the same time monitoring their activities on Twitter.

Elsewhere, we could use the United States President, Donald Trump's constant use of Twitter for the purpose of communication as an instance to justify the claim in the assertion above. But even in Nigeria, an avalanche of evidence abounds as well. Most of the political actors have their official twitter handles which they use to constantly update their fans with information. Also, spin doctors for the various politicians and political groups in the country have created Facebook profiles, pages and groups to supply the masses with information about such personnel or sects. This serves to demonstrate the centrality of the new media to the current 
democratic experiment in the country. Below are few case studies where the new media serve as facilitators of democracy in Nigeria's recent history.

\section{The 2015 General Elections}

The civil society deployed the arsenal of social media effectively to disseminate information during the 2015 general elections in Nigeria. According to Elegbede (20I5), during the period of campaign, Tweetmeets and Hangouts were the in-thing within Nigerian online socio-political networks. Hashtags such as \#MeetGej, \#Febuhari, \#Marchoutjonathan, \#WhyiwillvoteGEJ, \#MarchforBuhari, \#GMBI5, \#LagosForYou and \#iHavedecided were promoted by politicians and their supporters; while \#NigeriaDecides, \#Nigeria20I5, \#iPledgeToVote, \#MyPVCnow, \#GoVote, \#VoteNoFight, etc. were promoted by civil society groups to increase citizens' awareness and participation (see also Suntai and Targema 2015).

During the voting process, pictures and videos floated on Facebook and Watsapp accounts of party agents who were caught in the act buying voters with money and some other grants as well as the issue of underage voting in some states prompting immediate action by INEC. Similarly, during the collation of results, citizen journalists and the civil society never spared any effort to update the public on the nature of results in the various states across the federation (Oseni 2015).

Initially, the results were viewed skeptically as mere facades by the "zealous" APC, the opposition party that was bent to grab the mantle of leadership come what may. The masses were however, surprised to observe that when such results were eventually announced at the collation center, they used to tally with the citizen journalists' account on social media. In no time at all, the social media sites were saturated with subscribers who logged in to be updated on the elections. To quote Oseni $(2015,3)$ :

the trending results on social media made it clear to Nigerians that the APC had won in the north-east, north-west, south-west and was competing with PDP in the north central, while PDP led at the southsouth and south-east. Been agitated by the results trending on social media, PDP accused APC of posting fake election results on social media and further charged Nigerians to totally disregard results on social media and wait for official announcement by INEC... However, there was no significant difference between results announced by INEC and those trending on social media.

Analysts contend that the utilization of social media in the elections obviously frustrated Nigerian politicians and stopped the popular strategy of changing election results by returning officers in collaboration with political parties. All through the process of the elections, every citizen equipped with 
a mobile cell phone was an observer/reporter, ready to raise alarm to the virtual world/online community on any traces of malpractice or suspicion at any point in the election. This, alongside other forces, culminated into an election that was near free, fair and credible. Oseni $(2015,4)$ sums up his argument thus:

Social media age is a revolution to Nigerian democracy; those who must win election must win the will of the people. The days of changing election results by returning officers have gone. By the power of social media, citizens know who win elections before results are officially announced by the Independent National Electoral Commission INEC... social media has become a force and we must live up to this reality.

Emetumah (2016) stresses the role played by social media in the 2015 polls when he notes that the various platforms helped shape the opinion of a lot of youths in the election and increased the political awareness and consciousness of the youths in the country, the outcome of which was the emergence of an unbelievable win of opposition party (APC) over the ruling party (PDP) in the presidential election.

\section{Aftermath of the 2015 General Elections}

Two years into the government of President Mohammadu Buhari, the new media have continued to facilitate participatory democracy in the country by linking the government and the governed through the various discursive platforms it harbors. The key agenda of the government - antigraft war, economic recovery and security among others - have continued to stimulate engaging debates on the new media platforms. These debates helps to express the sentiments of the masses towards key policy decisions of the government to enable for adjustments where need be. In democratic rule, feedback from the masses is crucial to carry everybody along. This is where the new media come in, thus, they fill the information gap that hitherto existed, and facilitate free flow of information in the process of governance, both vertically and horizontally.

\section{Basic Threats Associated with the Practice}

While the new media appears to provide vibrant discursive channels that will facilitate democracy in the country, a careful observation of the trend reveal quite a number of threats that are not only worrisome, but have the capacity to diminish the opportunities which they offer to countries with budding democracies like Nigeria. First on the trail of such threats is the issue of hate and dangerous speech. This practice was really endemic in the 
build-up to the 2015 general elections, where the platforms were deployed to perpetuate campaigns of calumny against candidates with opposing views. So serious was the practice that it almost divided the country into the extremes of the Muslim-North and Christian-South.

Ibrahim, Pate, Pereira, Ya'u, Agbanyin and Bagu (20I7, 6) investigate the escalation of hate and dangerous speech in the build up to the 2015 election in the country and discover that: "there is extensive evidence of an explosion of hate and dangerous speech in Nigeria over the past decade, especially through the broadcast and social media as their major transmitters". The issue here is that, although the divide between North and South has existed in the country for long, new media platforms accentuated the division, and created an atmosphere full of enmity for one another during the 2015 elections. Sentiments that lie latent in the minds of people were given a voice, and widely expressed. This development poses a great threat to the fragile democracy which the country is striving to consolidate.

Similarly, Emetumah (20I6, I) reveals in his study that: "though social media helped in creating political awareness among Nigeria's electorates; they also served as negative propaganda platform for dissemination of hate speeches". The study which surveys opinions of 200 social media subscribers in Nigeria arrives at a conclusion, that:

Social media users grossly abused freedom of information offered through the medium in Nigeria's 2015 presidential election period... the two leading political parties (APC and PDP) accused themselves of spreading false information on social media using their followers. However, due to unavailability of regulatory outfit, politicians succeeded in using the platforms to disseminate unofficial and inaccurate results that created controversies among stakeholders and political parties in violation to electoral acts guiding elections in Nigeria. Thus, the platforms became a new ground for propagating unreliable election messages (Emetumah 20I6, 8).

Today, new media platforms have amplified the voices of secessionist groups in the country such as the Independent People of Biafra (IPOB), who are agitating for an independent state; the struggle which courts the various online media platforms gains momentum by the day, and is threatening the very foundation of Nigeria as a country. What this suggests is that in a diverse entity such as Nigeria, which is grappling with the herculean challenge of unity in diversity, new media platforms which present an unregulated free-for-all terrain can play a counter-progressive role, and pose serious challenges to the task of democratic consolidation.

\section{Concluding Remarks}


Conclusively, new media platforms are formidable forces in the consolidation of democracy. The information gap, which they help to bridge, benefits democracy in no small measure, and serves to strengthen the cherished principles of transparency and accountability in the process of governance. Nigerian democracy is speedily heading towards this enviable destination courtesy of the new media. Similarly, the new media platforms have extended the frontiers of political participation and interaction between the rulers and the ruled. This is a positive development that needs to be acknowledge, as it makes democracy in the country to live up to the expectations of its generic definition, as government of the people, for the people, and for the people.

However, the abuses that characterize the platforms are equally worrisome, given the threats they harbor, and the damage they portend for Nigeria's fragile democracy. In a country that is grappling with the challenge of unity in diversity, the various platforms if utilized otherwise can deepen the divides that already exist, and plunge the country into a deep dark ditch. Practices such as dissemination of outright lies and deliberate falsehood, dangerous, injurious and vituperative speech capable of spreading hatred among others can overheat the polity, and make nonsense of the budding democracy which the country strives to consolidate. On this note, the study recommends by borrowing the words of Suntai and Targema $(2015,16)$, that:

The civil society is hereby cautioned to exhibit a sense of responsibility in the process of online interaction through the process of self-regulation and rational judgment. In this way, the vices of social media will be minimized and its virtues maximized to enable it serve as an effective facilitator of democracy.

\section{REFERENCES}

Adeyanju A.M. 2013. "Mass Media and Public Opinion: Formation, Process and Uses". In Pate U. Nwabueze C. and Idiong, I. Politics, culture and the Media in Nigeria, pp. I83-204. Stirling Horden publishers: Ibadan.

Agudosy, F.I. 20I4. "The new media and sustainable economic development in Nigeria." Mass Media Review: An international Journal of Mass Communication. Vol. I No 4.

Alexander, O., Ifeanyi, A. L. and Martin, O. P. 2or6. "Preying on platforms: a comparative analysis of social media and traditional mass media advertisements in the 2015 presidential election campaigns in 
Nigeria". The Nigerian Journal of Communication: the Journal of the African Council for Communication Education (ACCE), Nigerian Chapter, I3(I), I-22.

Bitner, J. 1989. Mass communication: An introduction. Printece Hall: New Jersey

Elegbede, T. 20I5. Social media and governance in Africa. www.punch.com/ipunch/social-media-and-governance-in-africa/.

Emetumah, F.I. 20I6. "Social Media as a Factor for Increased Frontiers of Democracy in Nigeria's 2015 Presidential Election”. British Journal of Education, Society of Behavioural Science, I7(4), I-9,

Galadima, D. and Goshit, R. 2013. "The mass media and the challenges of Institutionalizing the culture of dialogue in Nigerian democracy". In Pate U., Nwabueze C. and Idiong, I. Politic, culture and the Media in Nigeria, pp.I57-I68. Ibadan: Stirling Horden publishers.

Gambo, D. 2013. "Media ethics, professionalism and the reportage of the electoral reform process in Nigeria". In Pate U. Nwabueze C. and Idiong, I. Politic, culture and the Media in Nigeria, pp.IoI-I22. Ibadan: Stirling Horden publishers.

Hanan, J. 2013. Using social media for good governance. http://b.worldbank. org/publicsphere/using-social-good-governance. Accessed I2 May 2015 .

Ibrahim, I., Pate, U., Pereira, C., Ya'u, Y.Z., Agbanyin, B.O. and Bagu, C. 2017. The escalation of hate and dangerous speech in the build up to the 2015 election and the imperative of strengthening the broadcasting code. A paper presented at the NBC Stakeholders Forum on Political Broadcasts, Chilla Luxury Suites, Kano. 26th October, 2017.

McQuail, D. 2005. Mass Communication Theory: An introduction. London: Sage Publications.

Nwabueze, C. 2009. Reporting: Principles, Approaches and Special Beats. Owerri: Top Shelve publishes.

Nwabueze, C. 20I4. Introduction to mass communication: media ecology in the global village. Owerri: Top Shelve publishes.

Olise, F.P. 20I4. "Social Media Emergence: Implications for Journalism Practice in Nigeria". Mass Media Review: An international Journal of Mass Communication. Vol.I No 4

Oseni, A.L. 20I5. How social media revolutionalized election in Nigeria. http:// benue.com.ng/how-social-media-revolutionalizes-nigerian- elections/. Accessed on 25 April, 20I4

Sambe, J.A. 2008. Introduction to mass communication practice in Nigeria. 


\title{
Ibadan: Spectrum Books
}

Suntai, D.I. and Targema, T.S. 20I5. Social media and democracy in Africa: assessing the 2015 general election experience in Nigeria. Paper presented at the International Conference on Democracy, Dictatorship and Development in Africa. Department of History and International Studies. Ibrahim Badamasi Babangida University, Lappi.2-5 August 2015 .

\begin{abstract}
Democracy in Nigeria, no doubt, gains momentum recently. This development coincides with an era of increased access to information by the masses courtesy of the new media and its numerous platforms and communication opportunities. Today, each member of the audience who is connected to the new media can not only access information, but can also create and share same on the various platforms for mass consumption. Democracy, which entails popular participation in the process of governance benefits immensely from this trend. This study explores the role new media plays in the consolidation of democracy in the country, with keen attention on the communication channels of the 2015 general elections, where new media championed the spread of information about the election, and the aftermath of the election period, that paved the way for the present administration. Anchored on the Social Responsibility Theory, the study interrogates the extent to which new media platforms liberalize the process of political communication in the country, and the opportunities and threats, which they harbor for democratic consolidation. The central argument in the study is that the new media presents a useful tool in the hands of activists and concerned citizens to participate in the government of the day and effectively play the watchdog role, a privilege which, hitherto, was far from reality. Sadly, however, several abuses exist that are threatening to rubbish the opportunities of the platform such as the prevalence of hate and dangerous speech, increased intensity of lies, mischiefs, falsehood and negative propaganda, and the use of comment sections to attack, verbally assault, bully and demonize co-discussants of political matters raised in the news via the numerous online platforms. To this end, the paper recommends a 'cautious' incorporation of the new media in the democratic process to pave the way for more participation.
\end{abstract}

\section{KEYWORDS}

New media; democracy; Nigeria; opportunities; threats.

Received on November 14, 2017. Approved on January 11, 2018. 